\title{
BNWL-242
}

5-

\section{THE EFFECT OF OXIDATION,}

THERMAL CYCLING, AND IRRADIATION

RESEARGH and

\section{DEVELOPMENT} REPORT
J. L. Jackson

August, 1966

\section{ON SILICON CARBIDE (SIC) COATED GRAPHITE}

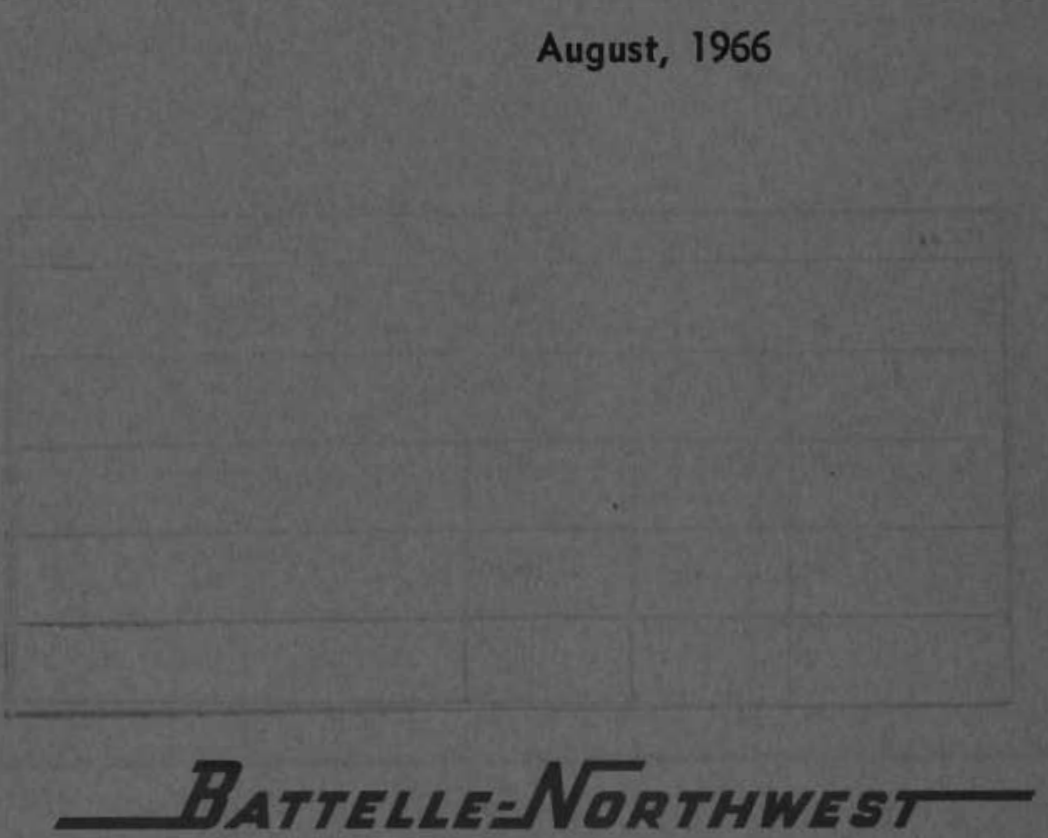

BATTELLE MEMORIAL INSTITUTE/PACIFIC NORTHWEST LABORATORY 


\section{LEGAL NOTICE}

This report was prepared as an account of Government sponsored work. Neither the United States, nor the Commission, nor any person acting on behalf of the Commission:

A. Makes any warranty or representation, expressed or implied, with respect to the accuracy, com. pleteness, or usefulness of the information contained in this report, or that the use of any information, apparatus, method, or process disclosed in this report may not infringe privately owned rights; or

B. Assumes any liabilities with respect to the use of, or for damages resulting from the use of any information, apparatus, method, or process disclosed in this report.

As used in the above, "person acting on behalf of the Commission" includes any employee or contractor of the Commission, or employee of such contractor, to the extent that such employee or contractor of the Commission, or employee of such contractor prepares, disseminates, or provides access to, any information pursuant to his employment or contract with the Commission, or his employment with such contractor

\section{PACIFIC NORTHWEST LABORATORY}

RICHLAND, WASHINGTON

operated by

BATTELLE MEMORIAL INSTITUTE

for the

UNITED STATES ATOMIC ENERGY COMMISSION UNDER CONTRACT AT(45-1)-1830 


\author{
BNWL -242 \\ UC-25, Meta1s, Ceramics, \\ and Materials \\ THE EFFECT OF OXIDATION, THERMAL CYCLING, AND IRRADIATION \\ ON SILICON CARBIDE ( $S$ IC) COATED GRAPHITE
}

\author{
By \\ J.L.Jackson \\ Ceramics and Graphite Research Section \\ Materials Department
}

August , 1966

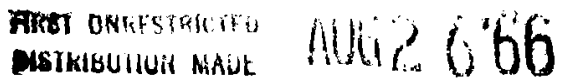

PACIFIC NORTHWEST LABORATORY

RICHLAND, WASHINGTON 
Printed in USA. Price $\$ 1.00$ Available from the Clearinghouse for Federal Scientific and Technical Information National Bureau of Standards

U. S. Department of Commerce Springfield, Virginia 


\section{THE EFFECT OF OXIDATION, THERMAL CYCLING, AND IRRADIATION ON SILICON CARBIDE ( $\mathrm{SIC}$ ) COATED GRAPHITE}

\section{INTRODUCTION}

Graphite is an excellent material for reactor cores, since it is a good neutron moderator that maintains its strength at high temperatures. One drawback to its use in gas-cooled reactors is its ready reaction with oxygen at temperatures in excess of $400{ }^{\circ} \mathrm{C}$. Oxidation may be prevented by the use of a protective coating, such as silicon carbide. In this study commercially available graphite specimens coated with silicon carbide were secured, and the effect of oxidation, thermal stress, and irradiation on their quality and integrity was investigated. The work covered two stages: an initial survey of the qualities of graphite substrates and coating methods that produced a useful artifact, and a test period in which samples of various shapes were tested for durability in an irradiation environment.

\section{SUMMARY}

A study of several commercial silicon-carbide coatings on different graphite substrates showed that the best coatings were 5 to $10 \mathrm{mils}$ thick and had no sharp corners. These coatings were best applied to substrates whose thermal expansions were close to silicon carbide. Good coatings with the above characteristics were affected very little by thermal cycling, oxidation, or irradiation.

\section{EXPERIMENTAL}

Description of Samples

The silicon-carbide-coated graphites and uncoated substrate samples used were provided by three different suppliers. The processes used to prepare the coated samples are proprietary, but the coatings can be generally classed as silicon carbide. In the beginning, each supplier selected the graphite substrate he preferred to coat; although, in the final shape test certain specific types were selected on the basis of data obtained from the initial survey tests.

The samples are coded in this report by number designating a particular type or grade of graphite used as a coating base and a letter designating a supplier. There were, in a11, six graphite types, three suppliers, and four shapes; however, not all types, suppliers, and shapes persisted through the entire testing period.

Figure 1 shows the general configuration of the samples studied. Figure 2 is a micrograph of a section of a typical coated graphite; the dark area at the top is mounting material, the grey and white area the coating, and the bottom grey area the graphite substrate. Note the penetration of coating into the graphite pores. 


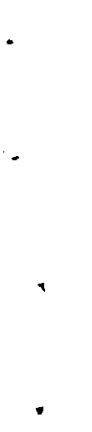




\section{Methods}

The first test was a simple oxidation test in which samples were weighed, then exposed to flowing air at $1000{ }^{\circ} \mathrm{C}$. Failed coatings were indicated by a weight loss. The test uncovered the more serious pre-existing coating failures but did not promote failure.

The next stage of testing approximated a more rigorous condition in which the substrate and the coating were thermally cycled over a large temperature range. The selected

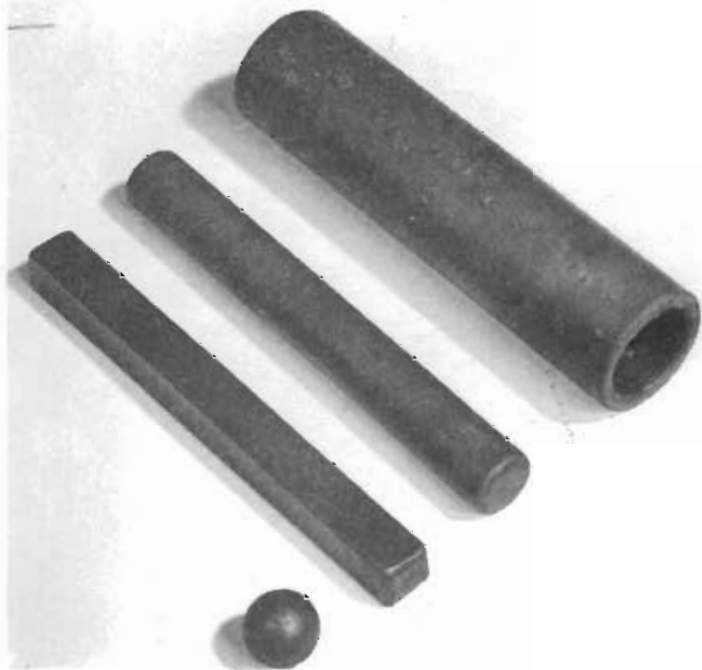

EIGURE 1. Coated Graphite Shapes

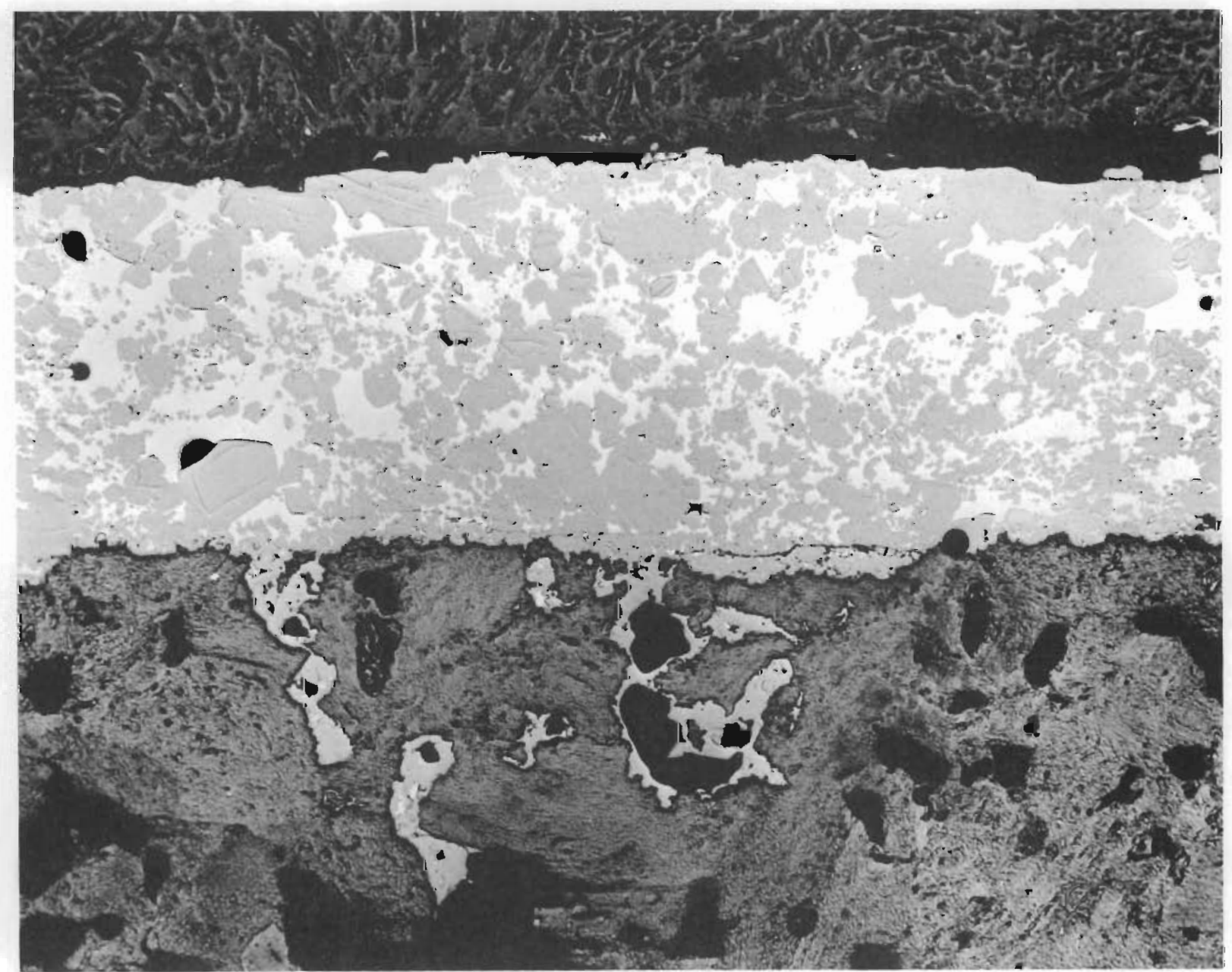


method of heating produced a thermal stress at the coating and substrate interface. (A high frequency induction furnace generated heat in the coating and produced a temperature gradient toward the center of the sample.) The heating system was programmed to cycle the sample temperature between 250 and $1200{ }^{\circ} \mathrm{C}$ at 6 to 7 cycles/hr. Once again, samples were in flowing air, and weight loss was measured to indicate coating failure.

Coated samples that survived the thermal-cycle test were then irradiated at $600 \pm 50{ }^{\circ} \mathrm{C}$ in a $\mathrm{He}-\mathrm{CO} 2$ atmosphere. Samples were weighed before and after irradiation. After irradiation, each specimen was again thermally cycled, and weight losses indicated coating failure. The type of data normally obtained on graphite, such as $\& \Delta \mathbf{L} /$ unit dose, was not obtainable since the SiC coated surfaces were not smooth enough to permit accurate measurement of length changes.

\section{DISCUSSION}

\section{Survey}

During the first part of the survey period, several different graphite substrates were tested to determine if any particular type of graphite substrate was best suited for coatings. Tests on 100 cylindrical samples (1) indicated that only graphites with a transverse-to-parallel thermal expansion ratio of 1.2 to 1.3 or less and with good radiation stability would provide "suitable" substrates. The coefficients of thermal expansion and radiation-induced dimensional changes for several graphite sub- strates are shown in Table I, Coat ings applied to these "suitable" substrates withstood considerable exposure to the high temperature, oxidizing atmospheres; in addition, irradiation produced no detectable effect on specimens that had successfully passed the oxidation test.

To provide a more severe environment, the thermal cycling tests were started. More candidates were eliminated since thermal cycling of about six times an hour from 250 to $1200{ }^{\circ} \mathrm{C}$ produced a thermal stress gradient in the thicker coatings which resulted in cracking. Coatings from 5 to 15 mils thick on samples with rounded corners were the most satisfactory; samples with sharp corners cracked at the corners. The result of one such failure is shown in Figure 3 .

After the first group of samples was irradiated to $\sim 3 \times 10^{20} \mathrm{nvt}$ and subsequently thermally cycled up to 1800 cycles, the necessity for selecting the correct coating substrate became apparent. Of the graphitebase materials studied, the two grades, Types 1 and 3 , which provided a good coating base, were fairly isotropic with thermal expansions near that of silicon carbide.

At the conclusion of this initial survey period, each supplier was provided with the data obtained from his particular coated samples.

\section{Shape}

Since it was apparent that a variety of coated shapes might be proposed for use in actual reactor construction, it was decided that effect of shape on the overall integrity of a SiC-coated artifact should be investigated. 


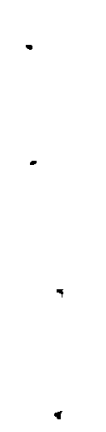


TABLE 1. Coatings Base Graphites

\begin{tabular}{|c|c|c|c|c|}
\hline Graphite & Orientation (a) & $\begin{array}{l}\text { CTE } \times 10^{6} /{ }^{\circ} \mathrm{C} \\
25 \text { to } 4255^{\circ} \mathrm{C} \\
\end{array}$ & $\begin{array}{c}\text { Ratio CTE } \\
\quad 1 / 1 \mathrm{I} \\
\end{array}$ & $\stackrel{\circ}{\mathrm{g}} \mathrm{L} /$ Unit Dose \\
\hline \multirow[t]{3}{*}{1} & 11 & 5.30 & & \\
\hline & & & 1.15 & \\
\hline & $\perp$ & 6.11 & & $+0.023^{(b)}$ \\
\hline 2 & Unknown & 4.30 & & -0.182 \\
\hline \multirow[t]{3}{*}{3} & 11 & 3.87 & & -0.034 \\
\hline & & & 1.28 & \\
\hline & $\perp$ & 4.97 & & +0.007 \\
\hline 4 & Unknown & 4.39 & & -0.282 \\
\hline \multirow[t]{3}{*}{5} & 11 & 2.34 & & $-0.060^{(b)}$ \\
\hline & & & 1.48 & \\
\hline & $\perp$ & 3.64 & & \\
\hline \multirow[t]{3}{*}{6} & 11 & 2.22 & & \\
\hline & & & 1.70 & \\
\hline & $\perp$ & 3.58 & & \\
\hline
\end{tabular}

Note: Coefficient of Thermal Expansion of $\mathrm{SiC}^{(2)}$ ranges from 4 to $5 \times 10^{-6}$ in./in. ${ }^{\circ} \mathrm{C}$.

(a) $\|$ and $\perp$, mean parallel and transverse to the direction of forming of the bar.

(b) Assumed orientation actual orientation on piece supplied is unknown.

FIGURE 3. Failea Silicon Carbide Coating 


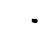

$\checkmark$ 
Two different graphites, Types 1 and 3 , were coated with a silicon carbide coating 6 to 8 mils thick. Specimens were produced (Figure l) by Supplier A in four basic shapes: balls, rods, rectangular parallelepipeds, and tubes (Figure 1). Two different coating methods were used. A section of one tube, shown in Figure 4, indicates the even deposition of coating that is possible both on the inside and outside of a tube. A total of 46 separate specimens were thermally cycled, irradiated, and thermally cycled again. The results of these last 46 tests are in Table II. Several samples were still sound after an irradiation exposure of $\sim 1 \times 10^{21}$ nvt at $600 \pm 50{ }^{\circ} \mathrm{C}$ and a total number of cycles both preand post-irradiation of $\sim 1800$.

\section{CONCLUSIONS}

The later tests confirmed the assumptions made during the survey period and allowed further conclusions to be drawn. The graphite used for the substrates must be as isotropic as possible with a coefficient of thermal expansion close to that of $\mathrm{SiC}$. The method of coating is critical and thermal cycle testing will soon eliminate poor methods. A coating thickness of from 5 to $15 \mathrm{mils}$ appears to be best, and the corners of the object should be rounded to prevent the coating from cracking. The effect of shape is small, and the effect of irradiation is negligible compared to the other factors.

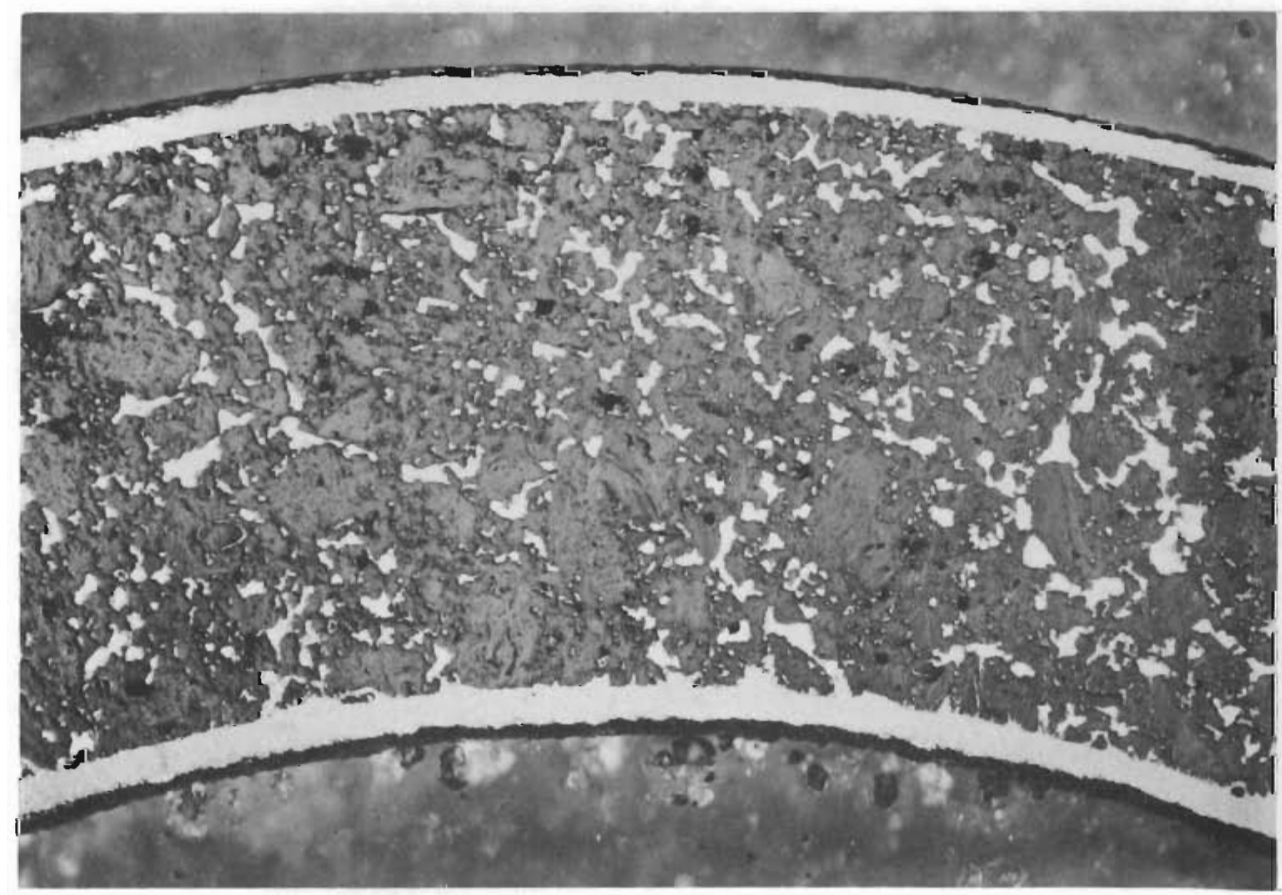

EIGURE 4. Section of Silicon Carbide Coated Graphite Tube 
$x$

. 


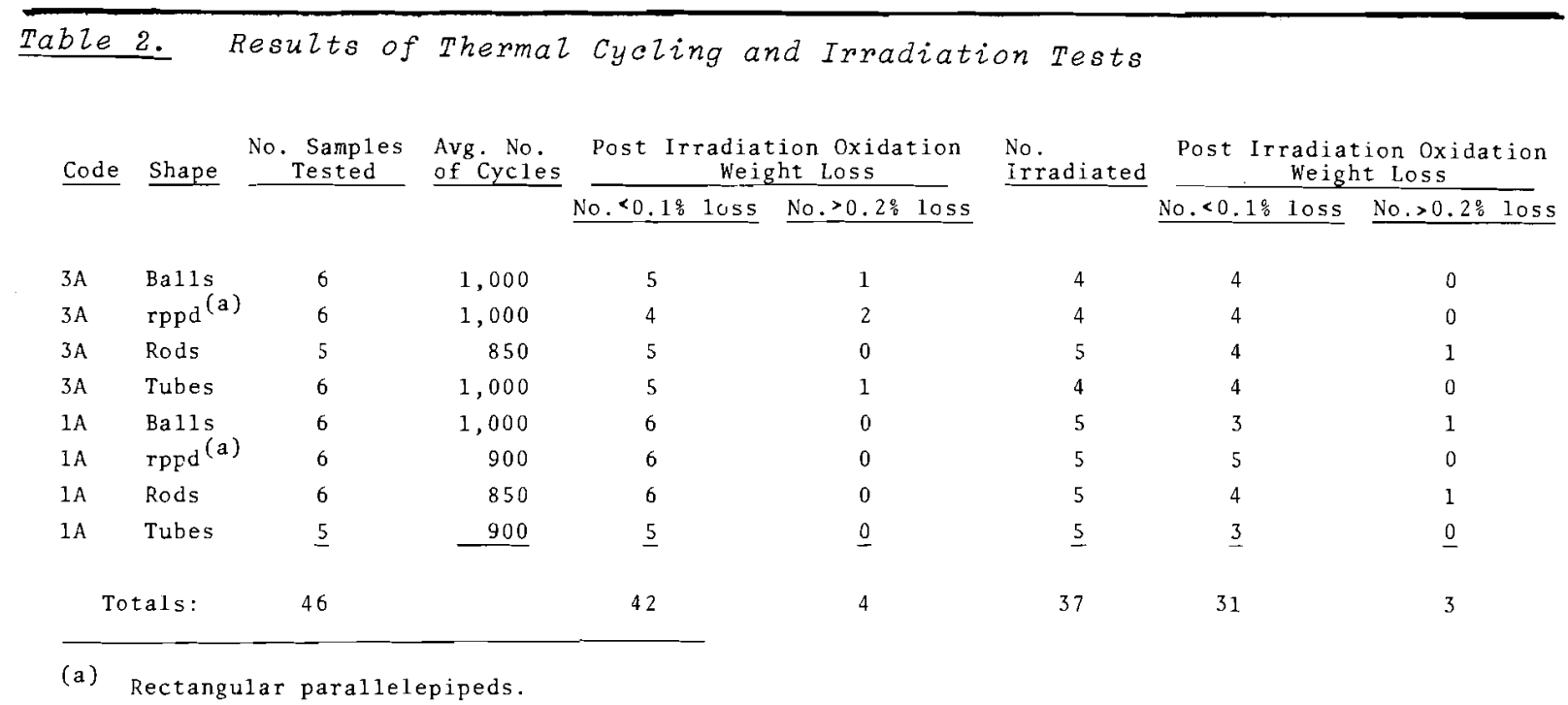

\section{ACKNOWLEDGEMENTS}

Samples for the tests were supplied by the Carbon Products Division of the Union Carbide Corporation, the Carborundum Company, and the Nuclear Products Division of the 3-M Company.

\section{REFERENCES}

1. J. L. Jackson. The Effect of Irradiation on Siliconized-Silicon Carbide Coatings for Graphite, HW-68494. 1961 .

2. A. Taylor and R. M. Jones. Silicon Carbide, edited by J.R. O'Connor and $J$. Smiztens, Pergamon Press, New York, 1960. pp. 147-154. 


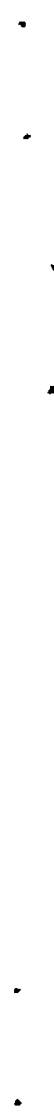




\section{DISTRIBUTION}

No. of

Copies

5

Atomic Energy Commission, Washington

Division of Reactor Dev.

J. E. Fox

J. Morrisey

R. Oeh 1

R. E. Pahler

J. M. Simmons

1 Atomics International

K. W. Foster

1 Atomic Power Development Associates

W. E. McHugh

1 Basic Carbon Company

Blank and Walmore Road

Sanborn, N.Y. 14132

K. M. Kil1ma r

326 Division of Technical

Information Extension

1 Douglas United Nuclear

A. Russel1

2 General Atomic Division

G. B. Engle

1 General Electric Company, Richland

D. H. Curtiss

2 Great Lakes Carbon Corp.

Research and Development Dept. P.0. Box 637

Niagara Falls, N.Y.

L. H. Juel, Electrode Div.

2 3-M Corporation

Nuclear Products Division

2501 Hudson Road

St. Paul, Minn.

H. H. Schroeder

1 Oak Ridge Operations Office

D. F. Cope
No. of

Copies

7 Richland Operations Office

L. R. Lucas (3)

R. L. P1um

R. K. Sharp

Technical Information Library

2 Speer Carbon Company

Research and Development Lab. Pakard Road and 47 th St. Niagara Falls, N.Y.

W. E. Parker

2 The Carborundum Co. P.O. Box 337 , Y Niagara Falls, N.Y.

1 PoCo Graphite, Inc.

P.0. Box 6118

Dallas, Texas 75222

R. K. Car1son

1 Pure Carbon Company, Inc. St. Marys, Penn. 15857

R. R. Paxton

2 Union Carbide Corporation, Cleveland

J. T. Meers

L. D. Stroughton

1 Union Carbide Corporation, Lawrenceburg, Tennessee

W. P. Earth1y

3 Union Carbide Corporation ( $Y-12)$

1 Wright Air Development Div. Wright-Patterson AFB, Ohio

W. G. Ramke

1 University of California Attn: Dr. James Hadley

103

Battelle-Northwest

F. W. Albaugh

D. E. Baker

L. R. Bunne11 


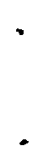


Battelle-Northwest (Contd)

R. E. Dah 1

D. R. de Halas

R. L. Dillon

P. L. Farnsworth

R. C. Giberson

J. W. Helm

J. L. Jackson

L. D. Johnson
W. C. Morgan

R. E. Nightingale

A. L. Pitner

G. L. Tingey

E. M. Woodruff

H. H. Yoshikawa

Technical Information Files (5)

Technical Publications (2) 
,

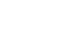

